\title{
EFFECT OF BIOFERTILIZERS INOCULATION METHODS AND SOME FOLIAR APPLICATION TREATMENTS ON YIELD AND QUALITY OF PEA PLANTS
}

Dawa. K. K.*; S. M. Farid** and A. E. El-Bauomy**.

* Veget. and Flori. Dept., Faculty of Agriculture, Mansoura University, Egypt.

${ }^{\star *}$ Veget. Res. Dept., Hort. Res. Inst., Agric. Res. Center, Egypt.

\section{ABSTRACT}

Two field experiments were conducted at a Private Farm near Aga, Dakahlia Governorate during two successive winter seasons of 2012/2013 and 2013/2014 to investigate the effect of bio-fertilizers inoculation method, some foliar application treatments and their interactions on vegetative growth characters, chemical constituents, yield and quality traits of pea (Pisum sativum L.). Four inoculation methods of bio-fertilizers (mixture of Rhizobium leguminosarum, Bacillus megatherium and Bacillus circulans), i.e, without inoculation, seeds inoculation pre-sowing, soil inoculation after germination and dual inoculation (seeds plus soil) and four foliar application treatments (control, seaweed extract at $2.5 \mathrm{ml} / \mathrm{l}$, ascorbic acid at $200 \mathrm{ppm}$ and yeast extract at $5 \mathrm{~g} / \mathrm{l}$ ). The data were recorded for yield and its components (pod length, pods weight/plant, No. of pods/plant, No. of green seeds/pod, weight of 100 green seeds and total yield/ fed.). Chemical constituents (N, P and $\mathrm{K} \%$ ) in leaves and pods. Pods quality (carbohydrates, crude protein, reducing, non reducing sugar and total sugar)

Obtained results showed that dual inoculation (seeds pre-sowing and soil after germination) combined with yeast extract as a foliar application surpassed other treatments in yield and its components, pods quality parameters and chemical constituents of leaves and pods.

Keywords: Pea (Pisum sativum L.), bio-fertilizers, seaweed extract, ascorbic acid and yeast extract

\section{INTRODUCTION}

Pea (Pisum sativum L.) is one of the most important leguminous vegetable crops grown during winter season in Egypt. It occupies a great figure in the local consumption and export. The total area grown with garden peas in Egypt was 47951 feddan, which produced 180631 ton with an average yield 3.77 ton/fed., While dry peas was 162 fed. and average productivity 0.77 ton/fed. (according to agricultural statistics, Ministry of Agriculture, 2012).

There is a great need for further studies under Egyptian condition to establish recommendation for reducing the amount of chemical NPK fertilizers to raise the quantity, improve the quality and limit the environmental pollution. Bio-fertilization has become in the last few decades a positive partial alternative to chemical fertilizers especially nitrogen and phosphorus fertilizers. Bio-fertilizers are very safe for human, animal and environment and using them reduce, at a lower extent, the great pollution occurred in our environment.

Recently, great attention has been focused on the possibility of using natural and safe substituents, i.e., seaweed extract, yeast extract and 
ascorbic acid in order to improve plant growth, flowering, fruit setting and total yield of horticultural plants. Seaweed extract is used as major bio-stimulant formulations in vegetable crops. Cytokinins and auxins have been identified and quantified in seaweed extract (Sanderson et al., 1987). These natural products has been shown to enhance plant growth in many vegetable crops under normal or stressed condition (Nour et al.,2010 on tomato; Hamed, 2012 on snap bean and Rathore et al., 2009 on soybean). Yeast extract is a natural bio-substance suggested to be of useful promotional and nutritional functions, due to their hormones, sugars, amino acids, nucleic acids, vitamins and minerals content. The positive effect of applying yeast extract in increasing yield and quality parameters of many vegetables was reported by many researchers (El-Desoki and El-Gereadly, 2006; Dawa et al., 2008 on pea and Dawa et al., 2013 on pepper) In addition, ascorbic acid (AsA) is one of the most important and abundantly occurring water soluble antioxidants in plants (Smirnoff, 2000b). ascorbic acid can be increased by exogenous application of AsA through the rooting medium (Chen and Gallie, 2004), as a foliar spray or as seeds priming. The positive effect of AsA application in many increasing yield and quality parameters of pea was reported by many researchers (Kamal and Abd Al-Gaid, 2008 and Gheeth et al.,2013 on pea)

This work aims to evaluate yield and its components, N,P,K percentage in leaves and pods, quality parameters of pea pods in response to different inoculation methods of bio-fertilizers, some foliar treatments and their interactions

\section{MATERIALS AND METHODS}

Two field experiments were conducted at a Private Farm near Aga, Dakahlia Governorate during two successive winter seasons of 2012/2013 and 2013/2014 to investigate the effect of bio-fertilizers inoculation method, some foliar application treatments and their interactions on some chemical constituents of leaves and pods, yield and quality traits of pea (Pisum sativum L.) cv. master B. The experiments of the study were executed in split plot in a randomized block design with four replicates. Bio-fertilizers treatments were presented in the main plots, while foliar application treatments were assigned in the sub plots. The sub plot area was $15 \mathrm{~m}^{2}$ which contained three ridges, each $5 \mathrm{~m}$ long and $1 \mathrm{~m}$ width, one row was left between each to experimental unit without spraying as a guard row to avoid the overlapping of spraying solution. Each experiment included 16 treatments comprising four inoculation methods of bio-fertilizers (mixture of Rhizobium leguminosarum, Bacillus megatherium and Bacillus circulans) and four foliar application treatments as follow:

\section{Bio-fertilizer inoculation methods:}

1- Without inoculation.

2- Seeds inoculation pre-sowing.

3- Soil inoculation (by injection after germination).

4- Seeds and soil inoculation. 
Bio-fertilizers treatment involved a mixture of beneficial microorganisms including Rhizobium leguminosarum, Bacillus megatherium bacteria which make phosphate more available and Bacillus circulans bacteria which make potassium more available. All inoculants were provided by bio-fertilizer unit, Fac. Agric., Ain Shams University.

The seeds were divided into two equal parts. The first part was inoculated with mixture bio-fertilizers, while the second part was un inoculated. The inoculation injection was added to the wet soil at the root absorption zone of each plant after 10 days from sowing.

\section{Foliar application treatments:}

1- Control (sprayed with tap water).

2- Seaweed extract at a rate of $2.5 \mathrm{ml} / \mathrm{l}$.

3- Ascorbic acid at a concentration of $200 \mathrm{ppm}$.

4- Yeast extract at a rate of $5 \mathrm{~g} / \mathrm{l}$. Active dry yeast mixed with sugar at ratio of $1: 1$ and dissolved in water, then left for 3 hours at room temperature. Then it was frozen for disruption of yeast tissue and releasing their content. Preparation of yeast solution was done according to El-Ghamriny et al. (1999).

Plants were sprayed three times with the different treatments as foliar spray starting after three weeks from sowing and repeated after 10 days from the last one. Each plot received $2 \mathrm{~L}$ solutions of each concentration using spreading agent in all treatments to improve adherence of the spray to the plant foliage for increasing seaweed extract, ascorbic acid and yeast extract absorption by plant. The untreated plants were sprayed with tap water and spreading agent.

\section{Cultural practices:}

The seeds were sown immediately in the moderately moist soil on 1st November 2012/2013 and 2013/2014 seasons. Seeds were sown in hills by hand at $10 \mathrm{~cm}$ apart on 6 rows of each ridge.

The mineral fertilization were added at a half recommended dose as; 30 $\mathrm{kg} \mathrm{N} / \mathrm{fed}$. in the form of ammonium nitrate $(33 \% \mathrm{~N})$ and $25 \mathrm{~kg} \mathrm{~K}{ }_{2} \mathrm{O} / \mathrm{fed}$. in the form of potassium sulfate $\left(50 \% \mathrm{~K}_{2} \mathrm{O}\right)$. The fertilizers $\mathrm{N}$ and $\mathrm{K}$ were divided in two equal doses, the first one was added before the first irrigation and the second one was before the following irrigation. Phosphorous fertilizer was 20 $\mathrm{kg} \mathrm{P}_{2} \mathrm{O}_{5} / \mathrm{fed}$. as form of calcium superphosphate $\left(15.5 \% \mathrm{P}_{2} \mathrm{O}_{5}\right)$, it was added during the experimental field preparation. During the growing seasons, all other agricultural practices were done as the recommendation of the Ministry of Agriculture, Egypt. The physical and chemical properties of the experimental soil have presented in Table (1) according to Chapman and Pratt (1971)

Data recorded:

\section{Plant Chemical composition:}

After 50 days from the sowing, a sample of 10 plants were randomly taken from each experimental unit and oven dried at $70^{\circ} \mathrm{C}$. Dried plant sample (leaves and seeds) were digested with sulphuric and perchloric acid (3:1) to determine $\mathrm{N}, \mathrm{P}$ and $\mathrm{K}$ of leaves and seeds: 
- Total nitrogen and total phosphorus content: were determined according the methods described by Jackson (1967) and potassium content: was determined according the methods described by Black (1965).

Yield and its components:

Green pods of each plot were harvested at the proper maturity stage, then the following parameters were recorded:

- Average pod length $(\mathrm{cm})$.

- Average pods weight/plant (g).

- Number pods/plant.

- No. of green seeds/pod.

- Weight of 100 green seeds $(\mathrm{g})$.

- Total yield: It was calculated as the total weight of pods (ton/fed.).

Table (1): Physical and chemical analysis of the experimental soil during 2012/2013 and 2013/2014 seasons.

\begin{tabular}{|c|c|c|c|}
\hline \multicolumn{2}{|c|}{ Physical properties } & First season & Second season \\
\hline \multicolumn{2}{|l|}{ O.M \% } & 1.32 & 1.21 \\
\hline \multicolumn{2}{|l|}{$\mathrm{CaCO} 3 \%$} & 3.05 & 2.87 \\
\hline \multicolumn{2}{|c|}{ Coarse sand \% } & 2.78 & 2.45 \\
\hline \multicolumn{2}{|c|}{ Fine Sand\% } & 29.32 & 30.16 \\
\hline \multicolumn{2}{|l|}{ Silt \% } & 33.56 & 35.05 \\
\hline \multicolumn{2}{|l|}{ Clay \% } & 34.34 & 32.34 \\
\hline \multicolumn{2}{|l|}{ S.p \% } & 62.5 & 61.4 \\
\hline \multicolumn{2}{|c|}{ Texture class } & Loamy & Loamy \\
\hline \multicolumn{4}{|c|}{ Chemical properties } \\
\hline \multicolumn{2}{|l|}{$\mathrm{pH}^{*}$} & 7.82 & 7.85 \\
\hline \multicolumn{2}{|l|}{$\mathrm{EC}^{* *} \mathrm{dS} / \mathrm{m}$} & 1.13 & 1.09 \\
\hline \multirow{6}{*}{$\begin{array}{l}\text { Available } \\
\text { (ppm) }\end{array}$} & $\mathrm{N}$ & 46.2 & 47.8 \\
\hline & $\mathrm{P}$ & 3.95 & 4.05 \\
\hline & $\mathrm{K}$ & 230 & 218 \\
\hline & $\mathrm{Fe}$ & 14.62 & 15.19 \\
\hline & $\mathrm{Zn}$ & 0.95 & 1.07 \\
\hline & $\mathrm{Mn}$ & 9.42 & 8.57 \\
\hline
\end{tabular}

*Soil suspension (1:2.5), ${ }^{*}$ Soil extraction (1:5), OM: Organic matter, SP: saturation percentage, EC: Electric conductivity

\section{Seed quality:}

A representative samples of $100 \mathrm{~g}$. of green seeds from each experimental plot were taken randomly and oven dried at $70^{\circ} \mathrm{C}$ to determine the following characters:

-Total carbohydrates: It were determined according to Somogy (1952).

-Reducing, non reducing sugar and total sugar: It was determined according to the method of Forsee (1938).

- Crude protein: It was calculated by multiplying the total nitrogen by the factor 6.25.

\section{Statistical analysis:}

The obtained data were subjected to statistical analysis as split plot design with four replicates in the both seasons according to Gomez and 
Gomez (1984).The differences between the treatments were compared using least significant differences (LSD at $5 \%$ level of significance) as described by Snedecor and Cochran (1967).

\section{RESULTS AND DISCUSSION}

\section{Yield and its components:}

Concerning the effect of bio-fertilizer on pod length, pod weight/plant, No. of pods/plant, No. of green seeds/pod, weight of 100 green seeds and total yield/ fed., data in Table (2) showed that all these parameters under investigation gave significant differences among the values of these parameters. The maximum value of all these parameters were executed for the treatment of dual inoculation (seeds and soil) followed by inoculation seeds only pre-sowing. The highest yield was obtained from treatment of inoculation seeds and soil (5.90 and 4.15 ton/fed. in the first and second season, respectively) While

the lowest yield was obtained with control treatment (without biofertilizer).

Data in the same Table also indicated that foliar spraying of pea plants with some foliar applications (seaweed extract, yeast extract and ascorbic acid) significantly increased the mean values of all these parameters as compared with the control treatment. For foliar application under study; spraying pea plants with yeast extract gave the highest values of all these parameters during both seasons.

The interaction effects between bio-fertilizer and foliar amendments on pea yield and its components (i.e, pod length, pod weight/plant, No. of pods/plant, No. of green seeds/pod, weight of 100 green seeds and total yield/ feddan) plants during the two seasons were presented in Table (3). It was obvious that foliar spraying of seaweed extract, yeast extract and ascorbic acid significantly increased the mean values of all parameters combined with all bio-fertilizer inoculation methods seeds or soil or seeds plus soil as compared with untreated plants. In this respect, foliar spraying of yeast extract combined with dual inoculation (seeds and soil) was superior for increasing the values of these parameters.

The obtained increment of yield and its components may be due to increase of vegetative growth characters. Hence vigorous growth increase in turn the amount of metabolites synthesized and dry matter accumulation by the plants as mentioned by Dawa et al. (2008) on pea and Dawa et al. (2013) on pepper. Moreover, the increase in total green pod yield owe directly to increase in both number and weight of pods as well as green pod yield/plant. These results were in agreement with those reported by Ghodia (2012) on cowpea.

Data of the same table also indicated that foliar spraying of pea plants with some foliar applications i.e, (seaweed extract, yeast extract and ascorbic acid) significantly increased the mean values of all these parameters as compared with the control treatment. 
Dawa. K. K. et al.

2 
J. Plant Production, Mansoura Univ., Vol. 5(11), November, 2014

3

1765 
For foliar application under study spraying with yeast extract gave the highest values of all these parameters during both seasons. The positive effects of applying yeast extract was attributed to its own contents of different nutrients, high percentage of protein, large amount of vitamin B and natural plant growth regulators such as cytokinins (Nagodawithana, 1991). Physiological roles of vitamins and amino acids in the yeast extract which increased the metabolic processes role and levels of endogenous hormones that may promote the vegetative growth parameters and reflected on enhancing yield. Also increasing pods yield response to yeast extract could be attributed to the increasing of total leaf area and dry matter accumulation, photosynthetic pigments and assimilates supply and hence enhancement of pods growth rates. Similar trend of results were reported by Tartoura (2001), El-Desoki and El-Gereadly (2006), Dawa et al. (2003) and (2008) on pea.

Respecting the yield and its components enhancing potential of the seaweed extract might be due to that seaweed extract is a bio-stimulant, which provide pea plants with micro, macro nutrients and significant amounts of cytokinins, auxins and betaines which increase chlorophyll production by boosting the photosynthetic process, thereby stimulating vegetative growth. So that, plant performance would be improved accordingly and reflect on its productivity. These results are in harmony with the findings of Nour et al. (2010) on tomato, Hamed (2012) on snap bean, Rathore et al. (2009) on soybean.

The increases in yield of pea and its components due to application of ascorbic acid may be due to that ascorbic acid is involved in the regulation of photosynthesis,enhancing cell division and expansion, root elongation, and trans-membrane electron transport (Smirnoff, 2000a).

Recent investigations revealed that ascorbate content regulates plant defense gene expression and modulate plant growth and development via phytohormone signaling (Pastori et al., 2003) thereby increased total yield.

These results are in the same line with those reported by Kamal and Abd AlGaid (2008) and Gheeth et al. (2013) on pea

\section{$\mathrm{N}, \mathrm{P}$ and $\mathrm{K}$ percentages in leaves and seeds:}

Concerning the effect of bio-fertilizer on nitrogen, phosphorus and potassium percentages in leaves and pods, data presented in Table (4) showed that $\mathrm{N}, \mathrm{P}$ and $\mathrm{K}$ percentages in leaves and pods were significantly increased with inoculation of seeds pre-sowing, soil after sowing and seeds plus soil compared to the control treatment (without inoculation) in both seasons. The highest values were obtained from plants inoculation of seeds plus soil followed by seeds inoculation only.

Regarding the effect of foliar applications on N, P and $\mathrm{K}$ contents in leaves and pods, data in the same Table showed that different foliar applications caused a significant increase in N, P and $\mathrm{K}$ percentages. The highest values were obtained from plants sprayed with yeast extract followed by ascorbic acid. 
J. Plant Production, Mansoura Univ., Vol. 5(11), November, 2014

4 
Concerning the effect of interaction between bio-fertilizer inoculation method and foliar applications on nitrogen, phosphorus and potassium contents in leaves and seeds, obtained results in Table (5) showed that N, P and K percentages were significantly increased under spraying plants with seaweed extract, yeast extract and ascorbic acid combined with all bio-fertilizer inoculation methods as compared to the untreated plants (without biofertilizers). The highest values were obtained from plants had dual inoculation (seed plus soil) combined with yeast extract, followed with spraying with ascorbic acid.

Regarding the significant enhancing effect of biofertilizer inoculation methods, it may be due to the positive effect on chemical composition in leaves by providing supplement doses of nutrient to the plants and in some cases providing plants with some promoting growth regulators. In addition, biofertilizer increase microorganisms living in the soil and these microorganisms working on the organic matter in the soil to convert organic $\mathrm{N}$ to mineral $\mathrm{N}$. Also biofertilizers play a fundamental role in converting $\mathrm{P}$ and $\mathrm{K}$ fixed form to be ready soluble for plant nutrition and making the uptake of nutrients by plants more easy. These results are in the same line with those reported by Dawa et al. (2008) on pea and Ghodia (2012) on cowpea.

Concerning the enhancement of seaweed extract on N, P and $\mathrm{K}$ percentages in leaves and pods, seaweed extract have been found to improve root system which could be influenced by endogenous auxins as well as other compounds in the extracts. Also, seaweed extracts improve nutrient uptake by roots (Crouch et al., 1990), resulting in root systems with improved water and nutrient efficiency, thereby causing enhanced general plant growth. Although they may contain different levels of minerals, bio-stimulants they are unable to provide all the nutrients needed by a plant in required quantities (Schmidt et al., 2003). However, their main benefit is to improve plant mineral uptake by roots (Vernieri et al., 2005) and in the leaves (Mancuso et al., 2006)

The enhancement effect of yeast extract on $\mathrm{N}, \mathrm{P}$ and $\mathrm{K}$ may be attributed to increases of leaf area and photosynthetic pigments thus increase photosynthesis process and hence more photosynthates being created as well as enhancement of mineral translocation from roots to leaves. This observation agrees with the reports of El-Desuki and El-Gereadly (2006) on pea, El-Tohamy and El-Gereadly (2007) on snap bean and Shokr and Fathy (2009) on snab bean.

Regarding the effect of ascorbic acid, Hager and Holocher (1994) reported that it is involved in the regulation of photosynthesis, cell expansion, root elongation, and trans-membrane electron transport and in several important enzyme reactions, such as violaxanthin deepoxidase these led to increase macro and micro element uptake. 
J. Plant Production, Mansoura Univ., Vol. 5(11), November, 2014

5

1769 


\section{Seed quality:}

Concerning the effect of bio-fertilizer on total carbohydrates, crude protein reducing, non reducing sugar and total sugar contents, data in Table (6) indicated that there were significant differences among bio-fertilizer inoculation methods for all quality parameters. The dual inoculation (seed and soil) was superior in increasing all mentioned parameters significantly except reducing sugars, since soil inoculation recorded the highest values.

With regard to the effect of foliar application under investigation on total carbohydrates, crude protein, reducing, non reducing sugar and total sugar contents in pea plants, data in Table (6) revealed a significant effect for foliar application treatments on pods quality in both seasons of the study. In this respect, it can be noticed that foliar spraying of yeast extract as foliar amendment generally was associated with the highest values of these parameters followed with ascorbic acid treatment.

Table (6): Effect of bio-fertilizer inoculation method and some foliar applications on seed quality traits of pea during $1^{\text {st }}(2012 / 2013)$ and $2^{\text {nd }}(2013 / 2014)$ seasons.

\begin{tabular}{|c|c|c|c|c|c|c|c|c|c|c|}
\hline Characters & \multicolumn{2}{|c|}{$\begin{array}{c}\text { Carbohydrates } \\
\%\end{array}$} & \multicolumn{2}{c|}{$\begin{array}{c}\text { Crude proteins } \\
\%\end{array}$} & \multicolumn{2}{c|}{$\begin{array}{c}\text { R. sugar } \\
\%\end{array}$} & \multicolumn{2}{c|}{$\begin{array}{c}\text { R. sugar } \\
\%\end{array}$} & \multicolumn{2}{c|}{$\begin{array}{c}\text { Total sugar } \\
\%\end{array}$} \\
\hline Treatments & $\begin{array}{c}\mathbf{1}^{\text {st }} \\
\text { season }\end{array}$ & $\begin{array}{c}\mathbf{2}^{\text {nd }} \\
\text { season }\end{array}$ & $\begin{array}{c}\mathbf{1}^{\text {st }} \\
\text { season }\end{array}$ & $\begin{array}{c}\mathbf{2}^{\text {nd }} \\
\text { season }\end{array}$ & $\begin{array}{c}\mathbf{1}^{\text {st }} \\
\text { season }\end{array}$ & $\begin{array}{c}\mathbf{2}^{\text {nd }} \\
\text { season }\end{array}$ & $\begin{array}{c}\mathbf{1}^{\text {st }} \\
\text { season }\end{array}$ & $\begin{array}{c}\mathbf{2}^{\text {nd }} \\
\text { season }\end{array}$ & $\begin{array}{c}\mathbf{1}^{\text {st }} \\
\text { season }\end{array}$ & $\begin{array}{c}\mathbf{2}^{\text {nd }} \\
\text { season }\end{array}$ \\
\hline \multicolumn{8}{|c|}{ Bio-fertilizer inoculation method } \\
\hline Without & 48.05 & 49.46 & 17.69 & 16.55 & 3.38 & 3.74 & 12.09 & 10.40 & 15.47 & 14.14 \\
\hline Seeds & 49.93 & 51.43 & 21.44 & 19.68 & 3.27 & 3.61 & 13.02 & 11.03 & 16.29 & 14.63 \\
\hline Soil & 49.00 & 50.49 & 19.61 & 18.23 & 3.64 & 4.03 & 12.21 & 10.40 & 15.86 & 14.44 \\
\hline Seeds+ Soil & 50.74 & 52.29 & 23.06 & 21.23 & 3.13 & 3.43 & 13.59 & 11.53 & 16.59 & 14.96 \\
\hline LSD at 5\% & 0.01 & 0.05 & 0.37 & 0.10 & 0.04 & 0.02 & 0.03 & 0.06 & 0.17 & 0.07 \\
\hline \multicolumn{8}{|c|}{ Foliar applications } \\
\hline Control & 48.88 & 50.29 & 19.23 & 17.82 & 3.16 & 3.48 & 12.67 & 10.74 & 15.71 & 14.23 \\
\hline Seaweed & 49.32 & 50.79 & 19.91 & 18.70 & 3.35 & 3.70 & 12.65 & 10.75 & 16.01 & 14.45 \\
\hline Yeast & 49.92 & 51.44 & 21.79 & 19.94 & 3.46 & 3.82 & 12.86 & 11.05 & 16.32 & 14.88 \\
\hline Ascorbic & 49.61 & 51.13 & 20.86 & 19.23 & 3.45 & 3.80 & 12.72 & 10.82 & 16.17 & 14.61 \\
\hline LSD at 5\% & 0.03 & 0.04 & 0.30 & 0.12 & 0.03 & 0.03 & 0.03 & 0.05 & 0.18 & 0.05 \\
\hline
\end{tabular}

*Mixture of Rhizobium leguminosarum, Bacillus megatherium and Bacillus circulans

R. sugar: reducing sugar, N. R. sugar: non-reducing sugar

As shown from the data presented in Table (7), the interaction between bio-fertilizer inoculation method and foliar applications had a significant effect on total carbohydrates, crude protein on reducing, non reducing sugar and total sugar in both seasons. The highest values were obtained from plants treated with dual inoculation (seed plus soil) combined with spraying yeast extract in all parameters except reducing sugars.

The increases in N, P and $\mathrm{K}$ percentages in seed may be due to the increases of these elements in the leaves which consequently translocated to seeds as shown in the Table (6). 
J. Plant Production, Mansoura Univ., Vol. 5(11), November, 2014 
The positive effects of seaweed treatment on the content of sugars and carbohydrates may be due to its enhancable effect on leaf area (photosynthetic surfaces), content of chlorophylls and content of some important minerals as shown by Dawa et al. (2013) on pepper, similar findings was reported by Rathore et al. (2009) on soybean and Hamed (2012) on snap bean. While the positive effect of yeast extract on quality parameters of pea is due to that yeast preparation contained carbohydrates, sugars, proteins, fatty acids, amino acids, hormones, macro and micro elements in suitable balance. The obtained results are in harmony with those of Tartoura (2001) on pea and Abd El-Hady (2014) on cucumber. Concerning the effect of ascorbic acid on the quality parameters of pea pods, The increments sugars total carbohydrates than the corresponding values of the control plants., these results could be explained by the findings obtained by Price (1966) who reported that ascorbic acid increased nucleic acid content, especially RNA and protein content of wheat grains. It also influenced by synthesis of enzymes, and proteins, in addition it acts as co-enzyme in metabolic changes (Reda et al., 1977; Fadl et al, 1978 and Abdel-Halim, 1995).

These results are in harmony with the findings of Kamal and Abd AlGaid (2008), Gheeth et al. (2013) on pea plants.

\section{REFERENCES}

Abd El-Hady, M. A. (2014). Effect of $\mathrm{N}$-forms and bio-stimulants on productivity of cucumber. Ph.D. Thesis, Fac. Agric., Damietta Univ., Egypt.

Abdel-Halim, S. M. (1995). Effect of some vitamins as growth regulators on growth, yield and endogenous hormones of tomato plants during winter. Egypt. J. Appl. Sci., 10(12) 322-334.

Black, C. A. (1965). "Methods of soil analysis". Part 1. Physical and mineralogical. A.S.A. Madison, Wise., USA.

Chapman, H. and P. Pratt (1971). Methods of analysis for soil, plants and waters. Univ. of California, Bull. No. 376, Davis, Cal., 96616. USA.

Chen, Z. and D. Gallie (2004). The ascorbic acid redox state controls guard cell signaling and stomatal movement. Plant Cell, 16: 1143-1162.

Crouch, I; R. Beckett and J. Van Staden (1990). Effect of seaweed concentrate on the growth and mineral nutrition of nutrient stressed lettuce. J. Appl. Phycol., 2: 269-272.

Dawa, K. K., E. A. Tartoura and M. A. Darweesh (2003). Effect of phosphorous fertilization and some growth promoters on growth and yield of pea (Pisum sativum L.). J. Agric. Sci. Mansoura Univ., 28(2): 1327-1343.

Dawa, K. K.; E. A. Tartoura and M. A. Darweesh (2008). Effect of some different (organic and bio) fertilizers and foliar application treatments on pea crops. J. Agric. Sci. Mansoura Univ., 33(5): 3573-3595.

Dawa, K. K.; H. M. Abd El-Nabi and W. M. Swelam, (2013). Response of sweet pepper plants (yield and fruit quality) to organic, biofertilizers and some foliar application treatments. The Seventh Arabian Conference for Horticulture. Ismailia, Egypt, March 24-26. 
El-Desuki, M. and N. El-Gereadly (2006). Response of pea plants to foliar application of yeast extract. J. Agric. Sci. Mansoura Univ., 31(10): 6667-6674.

El-Ghamriny, E. A.; H. M. Arisha and K. A. Nour (1999). Studies on tomato flowering, fruit set, yield and quality in summer season.1- Spraying with thiamine, ascorbic acid and yeast. Zagazig J. Agric. Res., 26(5): 13451364.

El-Tohamy, W. A. and El-Gereadly, N. H. (2007). Physiological responses, growth, yield and quality of snap beans in response to foliar application of yeast, vitamin $\mathrm{E}$ and zinc under sandy soil conditions. Australian $\mathrm{J}$. Basic and Appl. Sci., 1 (3): 294-299.

Fadl, M.; F. Reda; R. Abd-All and A. El-Moursi (1978). Physiological studies on Ammi visnaga L. Egypt. J. Physiol. Sci., 5(1): 73-83.

Forsee, W. T. (1938). Determination of sugar in plant materials a photoelectric method. Indus. Eng. Chem. Anal. Ed. 10: 411-418.

Gheeth, R. H.; Y. M. Moustafa and W. M. Abdel-Hakeem (2013). Ascorbic acid and cobalt chloride enhanced growth and increased production of peas. The Seventh Arabian Conference for Horticulture. Ismailia, Egypt, March 24-26.

Ghodia, R. H. A. (2012). Productivity improvement of cowpea under desert soil conditions. Plant Production, Mansoura Univ., 3(9): 2451-2463.

Gomez, K. A. and A. A. Gomez (1984). "Statistical Procedures for Agricultural Research". John Wiley and Sons, Inc., New York. pp: 680.

Hager, A. and K. Holocher (1994). Localization of the xanthophylls-cycle enzyme violaxanthin de-epoxidase within the thylakoid lumen and abolition of its mobility by a (light-dependent) $\mathrm{pH}$ decrease, Planta 89: 224-243.

Hamed, E. S. (2012). Effect of seaweed extract and compost treatments on growth, yield and quality of snap bean. Ph.D. Thesis, Fac. of Agric., Ain Shams. Univ., Egypt.

Jackson, M.L.(1967)."Soil chemical Analysis".Printico-Hall of India,New Delhi.

Kamal, A. M. and M. A. Abd Al-Gaid (2008). Effect of foliar application with some antioxidants on growth and yield of pea (Pisum sativum) under early planting conditions . J. Agric. Sci. Mansoura Univ., 33(10): 74137420.

Mancuso, S.; E. Azzarello, S. Mugnai and X. Briand (2006). Marine bioactive substances (IPA extract) improve ion fluxes and water stress tolerance in potted Vitis vinifera plants. Adv. Hort. Sci., 20: 156-161.

Nagodowithana, W. T. (1991). Yeast technology. Universal foods corporation Milwaukee, Wisconsin. Published by Van Nostrand Reinhold New Yourk. P. 237.

Nour, K. A. M.; N. T. S. Mansour and W. M. Abd EL-Hakim (2010). Influence of foliar spray with seaweed extracts on growth, setting and yield of tomato during summer season. J. Plant Production, Mansoura Univ., 1(7): 961-976. 
Pastori, G.; G. Kiddle; J. Antoniw; S. Bernard; S. Veljovic-Jovanovic; P. Verrier; G. Noctor and C. Foyer (2003). Leaf vitamin C contents modulate plant defense transcripts and regulate genes that control development through hormone signaling, Plant Cell, 15: 939-951.

Price, C. E. (1966). Ascorbate stimulation of RNA synthesis. Nature, 2121481.

Rathore, S. S.; D. R. Chaudhary; G. N. Boricha; A. Ghosh; B. P. Bhatt; S. T. Zodape and J. S. Patolia (2009). Effect of seaweed extract on the growth, yield and nutrient uptake of soybean (Glycine max) under rainfed conditions. South African J. Bot., 75(2): 351-355.

Reda, F.; M. Fadl ; R. Abd-All and A. El-Moursi (1977). Physiological studies on Ammi visnaga L. Egypt. J. Physiol. Sci., 18: 19-27.

Sanderson, K. J.; P. E. Jameson and J. A. Zabkiewicz (1987). Auxin in a seaweed extract: Identification and quantitation of indole-3-acetic acid by gas chromatography-mass spectrometry. J. Plant Physiol., 129:363367.

Schmidt, R.; E. Ervin and X. Zhang (2003). Question and answers about biostimulants. Golf Course Manage, 71: 91-94.

Shokr, M. M. and E. L. Fathy (2009). Some foliar applications for improving snap bean (Phaseolus Vulgaris L.) quality and yield at fall season. J. Agric. Sci. Mansoura Univ., 34(5): 5089-5106.

Smirnoff, N. (2000a). Ascorbic acid: Metabolism and functions of a multifaceted molecule. Curr. Opin. Plant Biol., 3: 229-235.

Smirnoff, N. (2000b). Ascorbate biosynthesis and function in photo protection. Biol. Sci., 355: 1455-1465.

Snedecor, W. G. and G. W. Cochran (1967). "Statistical Methods". Lowa State Univ. Press, Amer, USA. 6th Ed., PP.393.

Somogy, N. (1952). Notes on sugar determination. J. Biol. Chem., 195:19-23.

Tartoura, E. A. A. (2001). Response of pea plant to yeast extract and two sources of $\mathrm{N}$-fertilizers. J. Agric. Sci. Mansoura Univ. 26 (12): 78877901.

Vernieri, P.; E. Borghest; A. Ferranate and G. Magnani (2005). Application of biostimulants in floating system for improving rocket quality. J. Food Agric. Environ., 3: 86-88. 


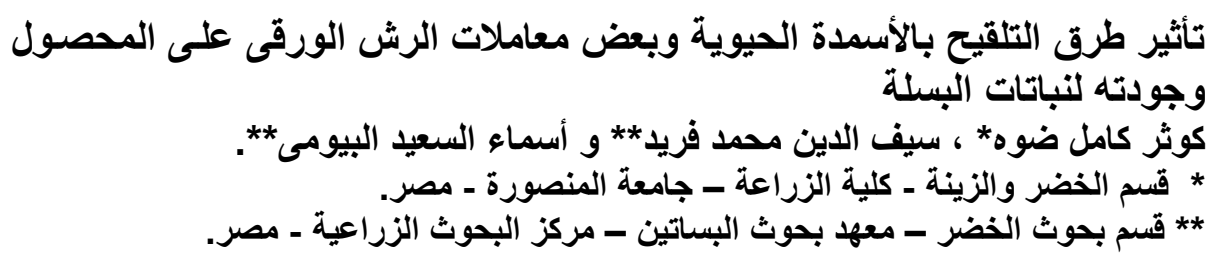

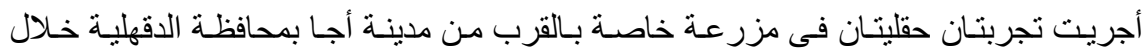

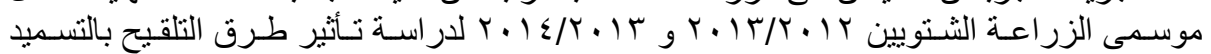

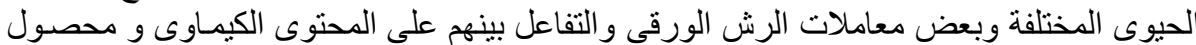

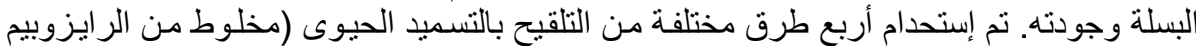

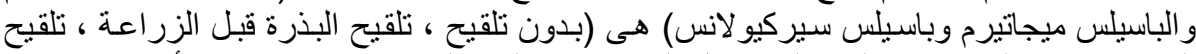

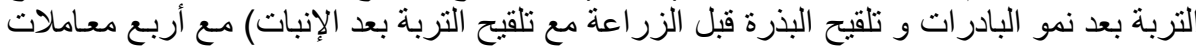

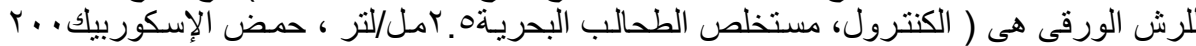

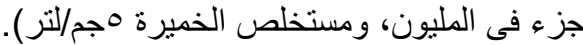

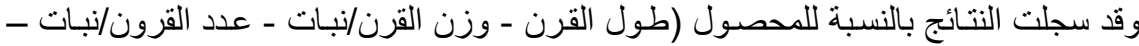

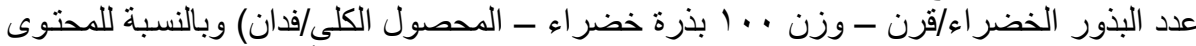

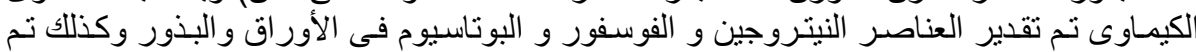

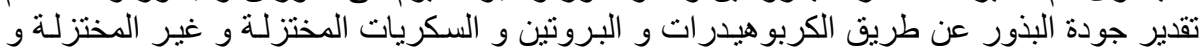

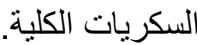

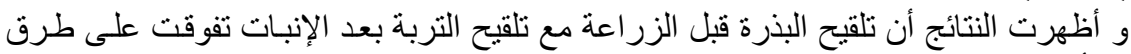

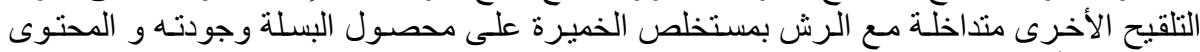

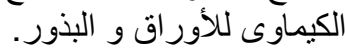


Dawa. K. K. et al. 
Table (2): Effect of bio-fertilizer inoculation method and some foliar applications on yield and its components of pea plants during $1^{\text {st }}(2012 / 2013)$ and $2^{\text {nd }}(2013 / 2014)$ seasons.

\begin{tabular}{|c|c|c|c|c|c|c|c|c|c|c|c|c|}
\hline \multirow{2}{*}{\begin{tabular}{|l} 
Characters \\
Treatments \\
\end{tabular}} & \multicolumn{2}{|c|}{$\begin{array}{l}\text { Pod length } \\
(\mathrm{cm})\end{array}$} & \multicolumn{2}{|c|}{$\begin{array}{c}\text { Pods } \\
\text { weight/plant } \\
\text { (g) }\end{array}$} & \multicolumn{2}{|c|}{ No. of pods/plant } & \multicolumn{2}{|c|}{$\begin{array}{l}\text { No. of green } \\
\text { seeds/pod }\end{array}$} & \multicolumn{2}{|c|}{$\begin{array}{l}\text { Weight of } 100 \\
\text { green seeds }(g)\end{array}$} & \multicolumn{2}{|c|}{$\begin{array}{l}\text { Total yield } \\
\text { (ton/fed.) }\end{array}$} \\
\hline & $\begin{array}{c}1^{\text {st }} \\
\text { season }\end{array}$ & $\begin{array}{c}2^{\text {nd }} \\
\text { season }\end{array}$ & $\begin{array}{c}1^{\text {st }} \\
\text { season }\end{array}$ & $\begin{array}{c}2^{\text {nd }} \\
\text { season }\end{array}$ & $\begin{array}{c}1^{\text {st }} \\
\text { season }\end{array}$ & $\begin{array}{c}2^{\text {nd }} \\
\text { season }\end{array}$ & $\begin{array}{c}1^{\text {st }} \\
\text { season }\end{array}$ & $\begin{array}{c}2^{\text {nd }} \\
\text { season }\end{array}$ & $\begin{array}{c}1^{\text {st }} \\
\text { season }\end{array}$ & $\begin{array}{c}2^{\text {nd }} \\
\text { season }\end{array}$ & $\begin{array}{c}1^{\text {st }} \\
\text { season }\end{array}$ & $\begin{array}{c}2^{\text {nd }} \\
\text { season }\end{array}$ \\
\hline \multicolumn{13}{|c|}{ Bio-fertilizer inoculation method $^{*}$} \\
\hline Without & 9.78 & 9.41 & 14.13 & 10.37 & 3.25 & 2.53 & 6.04 & 5.31 & 40.69 & 38.31 & 4.10 & 2.76 \\
\hline Seeds & 10.51 & 10.63 & 19.49 & 13.34 & 4.19 & 3.28 & 6.85 & 7.70 & 49.69 & 50.69 & 5.41 & 3.74 \\
\hline Soil & 10.28 & 10.06 & 17.92 & 11.66 & 3.82 & 2.93 & 6.48 & 6.50 & 46.25 & 45.50 & 4.95 & 3.18 \\
\hline Soil+ Seeds & 11.04 & 11.34 & 22.53 & 15.24 & 4.64 & 3.65 & 7.40 & 9.11 & 53.88 & 54.81 & 5.90 & 4.15 \\
\hline LSD at $5 \%$ & 0.19 & 0.15 & 1.66 & 1.21 & 0.23 & 0.17 & 0.09 & 0.15 & 1.93 & 1.20 & 0.31 & 0.24 \\
\hline \multicolumn{13}{|c|}{ Foliar applications } \\
\hline Control & 10.14 & 10.09 & 17.30 & 11.92 & 3.70 & 2.95 & 6.47 & 6.49 & 45.19 & 45.19 & 4.81 & 3.29 \\
\hline Seaweed & 10.31 & 10.33 & 18.12 & 12.46 & 3.94 & 3.08 & 6.64 & 7.20 & 46.94 & 47.25 & 5.00 & 3.43 \\
\hline Yeast & 10.64 & 10.59 & 19.60 & 13.42 & 4.17 & 3.23 & 6.90 & 7.53 & 50.12 & 48.81 & 5.36 & 3.59 \\
\hline Ascorbic & 10.51 & 10.44 & 19.04 & 12.81 & 4.09 & 3.14 & 6.78 & 7.38 & 48.25 & 48.06 & 5.18 & 3.51 \\
\hline LSD at $5 \%$ & 0.10 & 0.07 & 0.37 & 0.28 & 0.07 & 0.02 & 0.06 & 0.09 & 0.79 & 0.38 & 0.09 & 0.09 \\
\hline
\end{tabular}

* Mixture of Rhizobium leguminosarum, Bacillus megatherium and Bacillus circulans 
Dawa. K. K. et al. 
Table (3): Effect of interaction between bio-fertilizer inoculation methods and some foliar applications on yield and its components of pea plants during $1^{\text {st }}(2012 / 2013)$ and $2^{\text {nd }}(2013 / 2014)$ seasons.

\begin{tabular}{|c|c|c|c|c|c|c|c|c|c|c|c|c|c|}
\hline \multicolumn{2}{|c|}{ Characters } & \multicolumn{2}{|c|}{$\begin{array}{l}\text { Pod length } \\
\text { (cm) }\end{array}$} & \multicolumn{2}{|c|}{$\begin{array}{l}\text { Pods weight } \\
\text { /plant (g) }\end{array}$} & \multicolumn{2}{|c|}{$\begin{array}{c}\text { No. of } \\
\text { pods/plant }\end{array}$} & \multicolumn{2}{|c|}{$\begin{array}{l}\text { No. of green } \\
\text { seeds/pod }\end{array}$} & \multicolumn{2}{|c|}{\begin{tabular}{|l|} 
Weight of 100 \\
green seeds $(\mathrm{g})$
\end{tabular}} & \multicolumn{2}{|c|}{$\begin{array}{l}\text { Total yield } \\
\text { (ton/fed.) }\end{array}$} \\
\hline $\begin{array}{l}\text { Inoculation } \\
\text { methods }\end{array}$ & $\begin{array}{c}\text { Foliar } \\
\text { application }\end{array}$ & $\begin{array}{c}1^{\text {st }} \\
\text { season }\end{array}$ & $\begin{array}{c}2^{\text {nd }} \\
\text { season }\end{array}$ & $\begin{array}{c}1^{\mathrm{st}} \\
\text { season }\end{array}$ & $\begin{array}{c}2^{\text {nd }} \\
\text { season }\end{array}$ & $\begin{array}{c}1^{\text {st }} \\
\text { season }\end{array}$ & $\begin{array}{c}2^{\text {nd }} \\
\text { season }\end{array}$ & \begin{tabular}{c|}
$1^{\text {st }}$ \\
season
\end{tabular} & $\begin{array}{c}2^{\text {nd }} \\
\text { season }\end{array}$ & $\begin{array}{c}1^{\text {st }} \\
\text { season }\end{array}$ & $\begin{array}{c}2^{\text {nd }} \\
\text { season }\end{array}$ & $\begin{array}{c}1^{\text {st }} \\
\text { season }\end{array}$ & $\begin{array}{l}2^{\text {nd }} \\
\text { season }\end{array}$ \\
\hline \multirow{4}{*}{ Without } & Control & 9.50 & 9.20 & 11.98 & 9.84 & 2.83 & 2.39 & 5.73 & 4.24 & 38.00 & 36.00 & 3.64 & 2.64 \\
\hline & Seaweed & 9.70 & 9.40 & 14.11 & 10.36 & 3.21 & 2.50 & 6.03 & 5.55 & 40.75 & 38.25 & 3.97 & 2.78 \\
\hline & Yeast & 10.00 & 9.60 & 15.35 & 10.73 & 3.51 & 2.65 & 6.29 & 5.75 & 42.50 & 40.25 & 4.57 & 2.74 \\
\hline & Ascorbic & 9.90 & 9.45 & 15.06 & 10.55 & 3.44 & 2.58 & 6.14 & 5.69 & 41.50 & 38.75 & 4.21 & 2.88 \\
\hline \multirow{4}{*}{ Seeds } & Control & 10.30 & 10.40 & 18.76 & 12.59 & 4.03 & 3.13 & 6.66 & 7.24 & 48.00 & 48.75 & 5.20 & 3.58 \\
\hline & Seaweed & 10.50 & 10.60 & 18.91 & 13.09 & 4.18 & 3.26 & 6.76 & 7.64 & 49.25 & 50.75 & 5.32 & 3.74 \\
\hline & Yeast & 10.70 & 10.80 & 20.44 & 14.05 & 4.30 & 3.43 & 7.09 & 8.08 & 51.25 & 51.75 & 5.58 & 3.85 \\
\hline & Ascorbic & 10.55 & 10.70 & 19.84 & 13.64 & 4.26 & 3.33 & 6.90 & 7.84 & 50.25 & 51.50 & 5.52 & 3.78 \\
\hline \multirow{4}{*}{ Soil } & Control & 10.10 & 9.80 & 17.18 & 10.98 & 3.51 & 2.78 & 6.33 & 5.99 & 44.25 & 43.00 & 4.74 & 3.02 \\
\hline & Seaweed & 10.20 & 10.00 & 17.40 & 11.41 & 3.84 & 2.91 & 6.46 & 6.54 & 45.75 & 45.25 & 4.82 & 3.11 \\
\hline & Yeast & 10.45 & 10.30 & 18.79 & 12.36 & 4.03 & 3.05 & 6.61 & 6.81 & 48.00 & 47.25 & 5.19 & 3.40 \\
\hline & Ascorbic & 10.35 & 10.15 & 18.31 & 11.88 & 3.91 & 2.98 & 6.54 & 6.65 & 47.00 & 46.50 & 5.04 & 3.18 \\
\hline \multirow{4}{*}{$\begin{array}{l}\text { Soilt } \\
\text { Seeds }\end{array}$} & Control & 10.65 & 10.95 & 21.29 & 14.29 & 4.45 & 3.50 & 7.16 & 8.50 & 50.50 & 53.00 & 5.67 & 3.94 \\
\hline & Seaweed & 10.85 & 11.30 & 22.03 & 14.98 & 4.54 & 3.64 & 7.31 & 9.09 & 52.00 & 54.75 & 5.88 & 4.08 \\
\hline & Yeast & 11.40 & 11.65 & 23.84 & 16.53 & 4.83 & 3.78 & 7.61 & 9.50 & 58.75 & 56.00 & 6.09 & 4.37 \\
\hline & Ascorbic & 11.25 & 11.45 & 22.96 & 15.18 & 4.74 & 3.70 & 7.53 & 9.35 & 54.25 & 55.50 & 5.94 & 4.20 \\
\hline \multicolumn{2}{|l|}{ LSD at $5 \%$} & 0.24 & 0.19 & 1.73 & 1.55 & 0.26 & 0.17 & 0.12 & 0.20 & 2.25 & 1.32 & 0.32 & 0.27 \\
\hline
\end{tabular}

${ }^{*}$ Mixture of Rhizobium leguminosarum, Bacillus megatherium and Bacillus circulans 
Table (4): Effect of bio-fertilizer and some foliar applications on N, P and K percentages in pea leaves and seeds during $1^{\text {st }}(2012 / 2013)$ and $2^{\text {nd }}(2013 / 2014)$ seasons.

\begin{tabular}{|c|c|c|c|c|c|c|c|c|c|c|c|c|}
\hline \multirow{3}{*}{\begin{tabular}{|l} 
Characters \\
Treatments
\end{tabular}} & \multicolumn{6}{|c|}{ Leaves } & \multicolumn{6}{|c|}{ Green seeds } \\
\hline & \multicolumn{2}{|c|}{ N \% } & \multicolumn{2}{|c|}{$\mathbf{P} \%$} & \multicolumn{2}{|c|}{ K \% } & \multicolumn{2}{|c|}{ N \% } & \multicolumn{2}{|c|}{$\mathbf{P} \%$} & \multicolumn{2}{|c|}{ K \% } \\
\hline & \begin{tabular}{|c|}
$1^{\text {st }}$ \\
season
\end{tabular} & $\begin{array}{c}2^{\text {nd }} \\
\text { season }\end{array}$ & $\begin{array}{c}1^{\text {st }} \\
\text { season }\end{array}$ & $\begin{array}{c}2^{\text {nd }} \\
\text { season }\end{array}$ & \begin{tabular}{|c|}
$1^{\text {st }}$ \\
season
\end{tabular} & $\begin{array}{c}2^{\text {nd }} \\
\text { season }\end{array}$ & \begin{tabular}{|c|}
$1^{\mathrm{st}}$ \\
season
\end{tabular} & $\begin{array}{c}2^{\text {nd }} \\
\text { season }\end{array}$ & $\begin{array}{c}1^{\text {st }} \\
\text { season }\end{array}$ & $\begin{array}{c}2^{\text {nd }} \\
\text { season }\end{array}$ & $\begin{array}{c}1^{\text {st }} \\
\text { season }\end{array}$ & $\begin{array}{c}2^{\text {nd }} \\
\text { season }\end{array}$ \\
\hline \multicolumn{13}{|c|}{ Bio-fertilizer inoculation method* } \\
\hline Without & 3.36 & 3.22 & 0.268 & 0.263 & 1.74 & 2.01 & 2.83 & 2.65 & 0.390 & 0.345 & 1.42 & 1.55 \\
\hline Seeds & 3.96 & 3.76 & 0.327 & 0.314 & 2.15 & 2.48 & 3.43 & 3.16 & 0.457 & 0.403 & 1.82 & 1.96 \\
\hline Soil & 3.67 & 3.51 & 0.299 & 0.288 & 1.95 & 2.25 & 3.17 & 2.93 & 0.425 & 0.374 & 1.61 & 1.76 \\
\hline Seeds+ Soil & 4.22 & 4.02 & 0.358 & 0.344 & 2.34 & 2.74 & 3.69 & 3.40 & 0.481 & 0.424 & 1.98 & 2.17 \\
\hline LSD at $5 \%$ & 0.02 & 0.02 & 0.003 & 0.003 & 0.04 & 0.02 & 0.03 & 0.02 & 0.004 & 0.002 & 0.03 & 0.02 \\
\hline \multicolumn{13}{|c|}{ Foliar applications } \\
\hline Con & 3.68 & 3.52 & 0.299 & 0.288 & 1.94 & 2.27 & 3.08 & 2.86 & 0.416 & 0.368 & 1.57 & 1.72 \\
\hline Seaweed & 3.78 & 3.60 & 0.310 & 0.298 & 2.03 & 2.34 & 3.22 & 2.99 & 0.433 & 0.381 & 1.67 & 1.83 \\
\hline Yeast & 3.92 & 3.72 & 0.324 & 0.316 & 2.14 & 2.47 & 3.49 & 3.21 & 0.459 & 0.402 & 1.84 & 2.01 \\
\hline Ascorb & 3.84 & 3.66 & 0.318 & 0.306 & 2.08 & 2.41 & 3.34 & 3.08 & 0.445 & 0.394 & 1.76 & 1.89 \\
\hline LSD at $5 \%$ & 0.02 & 0.03 & 0.002 & 0.002 & 0.02 & 0.02 & 0.03 & 0.02 & 0.002 & 0.003 & 0.02 & 0.02 \\
\hline
\end{tabular}

*Mixture of Rhizobium leguminosarum, Bacillus megatherium and Bacillus circulans 
J. Plant Production, Mansoura Univ., Vol. 5(11), November, 2014 
Table (5): Effect of interaction between bio-fertilizer and some foliar applications on $\mathrm{N}, \mathrm{P}$ and $\mathrm{K}$ percentages in pea leaves and seeds during $1^{\text {st }}(2012 / 2013)$ and $2^{\text {nd }}(2013 / 2014)$ seasons.

\begin{tabular}{|c|c|c|c|c|c|c|c|c|c|c|c|c|c|}
\hline \multirow{2}{*}{\multicolumn{2}{|c|}{ Characters }} & \multicolumn{6}{|c|}{ Leaves } & \multicolumn{6}{|c|}{ Green seeds } \\
\hline & & \multicolumn{2}{|c|}{$\mathbf{N} \%$} & \multicolumn{2}{|c|}{$\mathbf{P} \%$} & \multicolumn{2}{|c|}{ K \% } & \multicolumn{2}{|c|}{$\mathbf{N} \%$} & \multicolumn{2}{|c|}{ P \% } & \multicolumn{2}{|c|}{ K \% } \\
\hline $\begin{array}{l}\text { Inoculation } \\
\text { methods }\end{array}$ & $\begin{array}{c}\text { Foliar } \\
\text { application }\end{array}$ & $\begin{array}{c}1^{\text {st }} \\
\text { season }\end{array}$ & \begin{tabular}{|c|}
$2^{\text {nd }}$ \\
season
\end{tabular} & \begin{tabular}{c|}
$1^{\mathrm{st}}$ \\
season
\end{tabular} & $\begin{array}{c}2^{\text {nd }} \\
\text { season }\end{array}$ & $\begin{array}{c}1^{\text {st }} \\
\text { season }\end{array}$ & $\begin{array}{c}2^{\text {nd }} \\
\text { season }\end{array}$ & $\begin{array}{c}1^{\text {st }} \\
\text { season }\end{array}$ & \begin{tabular}{|c|}
$2^{\text {nd }}$ \\
season
\end{tabular} & $\begin{array}{c}1^{\text {st }} \\
\text { season }\end{array}$ & \begin{tabular}{|c|}
$2^{\text {nd }}$ \\
season
\end{tabular} & $\begin{array}{c}1^{\mathrm{st}} \\
\text { season }\end{array}$ & $\begin{array}{c}2^{\text {nd }} \\
\text { season }\end{array}$ \\
\hline \multirow{4}{*}{ Without } & Control & 3.25 & 3.14 & 0.255 & 0.248 & 1.65 & 1.92 & 2.60 & 2.48 & 0.370 & 0.327 & 1.25 & 1.39 \\
\hline & Seaweed & 3.33 & 3.17 & 0.265 & 0.254 & 1.68 & 1.96 & 2.77 & 2.58 & 0.389 & 0.342 & 1.40 & 1.51 \\
\hline & Yeast & 3.47 & 3.31 & 0.279 & 0.287 & 1.84 & 2.11 & 3.06 & 2.84 & 0.408 & 0.361 & 1.56 & 1.69 \\
\hline & Ascorbic & 3.40 & 3.25 & 0.273 & 0.263 & 1.79 & 2.07 & 2.90 & 2.68 & 0.396 & 0.350 & 1.50 & 1.61 \\
\hline \multirow{4}{*}{ Seeds } & Control & 3.84 & 3.61 & 0.312 & 0.299 & 2.04 & 2.34 & 3.27 & 3.00 & 0.436 & 0.383 & 1.66 & 1.83 \\
\hline & Seaweed & 3.95 & 3.78 & 0.325 & 0.314 & 2.17 & 2.49 & 3.33 & 3.08 & 0.446 & 0.396 & 1.78 & 1.93 \\
\hline & Yeast & 4.06 & 3.85 & 0.338 & 0.324 & 2.23 & 2.59 & 3.67 & 3.36 & 0.481 & 0.421 & 1.97 & 2.12 \\
\hline & Ascorbic & 4.00 & 3.81 & 0.333 & 0.319 & 2.19 & 2.52 & 3.45 & 3.20 & 0.464 & 0.413 & 1.86 & 1.98 \\
\hline \multirow{4}{*}{ Soil } & Control & 3.51 & 3.41 & 0.287 & 0.275 & 1.87 & 2.20 & 2.92 & 2.70 & 0.399 & 0.353 & 1.49 & 1.61 \\
\hline & Seaweed & 3.62 & 3.44 & 0.295 & 0.285 & 1.93 & 2.23 & 3.13 & 2.91 & 0.420 & 0.369 & 1.56 & 1.71 \\
\hline & Yeast & 3.81 & 3.63 & 0.312 & 0.300 & 2.02 & 2.30 & 3.36 & 3.11 & 0.448 & 0.392 & 1.76 & 1.94 \\
\hline & Ascorbic & 3.74 & 3.55 & 0.303 & 0.294 & 1.97 & 2.27 & 3.26 & 3.00 & 0.432 & 0.382 & 1.63 & 1.78 \\
\hline \multirow{4}{*}{ Soil+ Seeds } & Control & 4.12 & 3.91 & 0.344 & 0.331 & 2.22 & 2.61 & 3.52 & 3.26 & 0.461 & 0.409 & 1.88 & 2.05 \\
\hline & Seaweed & 4.23 & 4.03 & 0.357 & 0.341 & 2.32 & 2.69 & 3.64 & 3.38 & 0.477 & 0.420 & 1.94 & 2.15 \\
\hline & Yeast & 4.32 & 4.10 & 0.368 & 0.355 & 2.45 & 2.89 & 3.86 & 3.52 & 0.499 & 0.437 & 2.07 & 2.29 \\
\hline & Ascorbic & 4.22 & 4.03 & 0.362 & 0.348 & 2.39 & 2.79 & 3.74 & 3.44 & 0.487 & 0.433 & 2.05 & 2.20 \\
\hline \multicolumn{2}{|l|}{ LSD at $5 \%$} & 0.04 & 0.05 & 0.004 & 0.005 & 0.04 & 0.04 & 0.05 & 0.04 & 0.005 & 0.005 & 0.05 & 0.04 \\
\hline
\end{tabular}

${ }^{\star}$ Mixture of Rhizobium leguminosarum, Bacillus megatherium and Bacillus circulans 
Table (7): Effect of interaction between bio-fertilizer inoculation method and some foliar applications on seed quality of pea pods during $1^{\text {st }}(2012 / 2013)$ and $2^{\text {nd }}(2013 / 2014)$ seasons.

\begin{tabular}{|c|c|c|c|c|c|c|c|c|c|c|c|}
\hline \multicolumn{2}{|c|}{ Characters } & \multicolumn{2}{|c|}{$\begin{array}{c}\text { Carbohydrates } \\
\%\end{array}$} & \multicolumn{2}{|c|}{$\begin{array}{c}\text { Crude proteins } \\
\%\end{array}$} & \multicolumn{2}{|c|}{$\begin{array}{c}\text { R. sugar } \\
\%\end{array}$} & \multicolumn{2}{|c|}{$\begin{array}{c}\text { N. R. sugar } \\
\%\end{array}$} & \multicolumn{2}{|c|}{$\begin{array}{c}\text { Total sugar } \\
\%\end{array}$} \\
\hline $\begin{array}{l}\text { Inoculation } \\
\text { methods }\end{array}$ & $\begin{array}{c}\text { Foliar } \\
\text { application }\end{array}$ & $\begin{array}{c}1^{\text {st }} \\
\text { season }\end{array}$ & $\begin{array}{c}2^{\text {nd }} \\
\text { season }\end{array}$ & $\begin{array}{c}1^{\text {st }} \\
\text { season }\end{array}$ & $\begin{array}{c}2^{\text {nd }} \\
\text { season }\end{array}$ & $\begin{array}{c}1^{\text {st }} \\
\text { season }\end{array}$ & $\begin{array}{c}2^{\text {nd }} \\
\text { season }\end{array}$ & $\begin{array}{c}1^{\text {st }} \\
\text { season }\end{array}$ & $\begin{array}{c}2^{\text {nd }} \\
\text { season }\end{array}$ & $\begin{array}{c}1^{\text {st }} \\
\text { season }\end{array}$ & $\begin{array}{l}2^{\text {nd }} \\
\text { season }\end{array}$ \\
\hline \multirow{4}{*}{ Without } & Control & 47.52 & 48.88 & 16.25 & 15.65 & 3.34 & 3.70 & 11.85 & 10.15 & 15.20 & 13.86 \\
\hline & Seaweed & 47.91 & 49.35 & 17.29 & 16.21 & 3.38 & 3.73 & 12.00 & 10.19 & 15.39 & 13.92 \\
\hline & Yeast & 48.55 & 50.01 & 19.13 & 17.69 & 3.42 & 3.81 & 12.32 & 10.90 & 15.75 & 14.71 \\
\hline & Ascorbic & 48.23 & 49.62 & 18.11 & 16.64 & 3.38 & 3.71 & 12.19 & 10.37 & 15.56 & 14.08 \\
\hline \multirow{4}{*}{ Seeds } & Control & 49.31 & 50.80 & 20.41 & 18.64 & 3.24 & 3.53 & 12.81 & 10.73 & 16.05 & 14.27 \\
\hline & Seaweed & 49.80 & 51.20 & 20.81 & 19.17 & 3.24 & 3.59 & 12.97 & 11.00 & 16.22 & 14.60 \\
\hline & Yeast & 50.47 & 51.99 & 22.95 & 20.84 & 3.32 & 3.67 & 13.17 & 11.25 & 16.50 & 14.92 \\
\hline & Ascorbic & 50.16 & 51.72 & 21.58 & 20.08 & 3.29 & 3.63 & 13.13 & 11.12 & 16.40 & 14.75 \\
\hline \multirow{4}{*}{ Soil } & Control & 48.40 & 49.78 & 18.28 & 16.75 & 3.09 & 3.43 & 12.55 & 10.73 & 15.65 & 14.16 \\
\hline & Seaweed & 48.93 & 50.44 & 18.81 & 18.20 & 3.74 & 4.13 & 12.05 & 10.26 & 15.80 & 14.40 \\
\hline & Yeast & 49.49 & 51.02 & 20.99 & 19.20 & 3.90 & 4.30 & 12.23 & 10.40 & 16.13 & 14.71 \\
\hline & Ascorbic & 49.19 & 50.70 & 20.36 & 18.76 & 3.85 & 4.26 & 12.01 & 10.22 & 15.87 & 14.49 \\
\hline \multirow{4}{*}{ Soil+ Seeds } & Control & 50.28 & 51.71 & 21.99 & 20.26 & 2.99 & 3.27 & 13.49 & 11.35 & 15.95 & 14.62 \\
\hline & Seaweed & 50.64 & 52.20 & 22.73 & 21.21 & 3.04 & 3.35 & 13.59 & 11.54 & 16.61 & 14.90 \\
\hline & Yeast & 51.19 & 52.76 & 24.11 & 22.01 & 3.21 & 3.52 & 13.70 & 11.65 & 16.92 & 15.18 \\
\hline & Ascorbic & 50.86 & 52.50 & 23.39 & 21.46 & 3.29 & 3.59 & 13.57 & 11.56 & 16.86 & 15.15 \\
\hline \multicolumn{2}{|c|}{ LSD at $5 \%$} & 0.06 & 0.08 & 0.60 & 0.22 & 0.06 & 0.05 & 0.06 & 0.09 & 0.34 & 0.11 \\
\hline
\end{tabular}

${ }^{\star}$ Mixture of Rhizobium leguminosarum, Bacillus megatherium and Bacillus circulans

R. sugar: reducing sugar, N. R. sugar: non-reducing sugar 
Dawa. K. K. et al. 